\title{
RESIDUAL PROPERTIES OF FIBER-REINFORCED REFRACTORY COMPOSITES WITH A FIRECLAY FILLER
}

\author{
Marcel Jogl, Pavel Reiterman*, Ondřej Holčapek, \\ Jaroslava Kơ̌ÁtKová, Petr Konvalinka
}

\author{
Czech Technical University in Prague, Faculty of Civil Engineering, Experimental Centre, Thákurova 7, 16629 \\ Prague 6, Czech Republic \\ * corresponding author: pavel.reiterman@fsv.cvut.cz
}

\begin{abstract}
The aim of our study was to develop a composite material for industrial use that is resistant to the effect of high temperatures. The binder system based on aluminous cement was modified by adding finely-ground ceramic powder and metakaolin to reduce costs and also to reduce adverse effects on the environment due to high energy consumption for cement production. Additives were applied as a partial aluminous cement replacement in doses of 10,20 and $30 \%$ by weight. The composites were evaluated on the basis of their mechanical properties and their bulk density after gradual temperature loading. The influence of basalt fibers and modifications to the binder system were studied at the same time. Basalt fibers were applied in doses of $0.5 \%$ and $2.0 \%$ by volume. The results confirmed the potential of the mineral additives studied here for practical applications, taking into account the residual mechanical parameters after thermal loading. The addition of ceramic powder reduced the bulk density by $5 \%$ for each $10 \%$ of cement substitution, but the residual values were very similar. The bulk density and the compressive strength were reduced when basalt fibers were applied, and the flexural strength was significantly increased in proportion to the fiber dosages. Metakaolin seems to be a more suitable additive than the ceramic powder that was applied here, because there was a significant increase in the mechanical parameters and also in the residual values of all properties that were studied.
\end{abstract}

KEYworDs: temperature loading; fireclay filler; aluminous cement; metakaolin additive; ceramic powder; basalt fibres; mechanical properties.

\section{INTRODUCTION}

Refractories are composite materials developed for high temperature applications to protect industrial technologies, structures, and also people. The composites investigated here are made from high-utility, high-quality materials. This has a significant influence on their price and on the amount of energy consumption. Heat-resistant materials can be divided into several classes, based on: chemical composition (acid, basic and special), method of implementation (shaped and unshaped), method of manufacture (fused and sintered), and porosity content (porous and dense) [1, 2]. The major categories of traditional refractories are fireclays, high alumina, and silica. One of the best-known techniques for producing refractory composites is by mixing selected components and then casting them to obtain the required shape 3 . The choice of material for traditional refractory applications, and also for advanced material applications, has always been based on balancing costs and performance lifetime [1].

The residual properties of refractories are often ensured by applying a fiber reinforcement, which helps to resist predominantly tension stresses emerging from volume changes. Increasing tensile strength of the final composite reduces crack initiation [4-7]. The fibres can be made from natural materials such as asbestos, sisal, basalt and cellulose, or from manufactured prod- ucts such as glass, steel, carbon and polymers 8]. However, a number of these fibres cannot be successfully applied in fire-resistant composites, due to their combustibility or low heat resistance. Basalt and carbon fibers are most widely used, due to their suitable mechanical and durability properties, and the absence of health risks 9 .

Traditional Portland cement-based concrete undergoes sequences of structural changes according to the actual thermal load level. After evacuation of the physically bonded water at $200^{\circ} \mathrm{C}$ and gradual decomposition of $\mathrm{CSH}$, there is a crucial temperature level at about $400^{\circ} \mathrm{C}$ when portlandite $\mathrm{Ca}(\mathrm{OH})_{2}$, an important hydration product, decomposes to quicklime and water [10]. When a thermal load of $573^{\circ} \mathrm{C}$ is reached, there is crystal lattice transformation of quartz, which is accompanied by extensive volume changes and crack formation. Increasing the thermal level causes loss of integrity. The origin of the ceramic bond was observed, but the weak binding ability of this system cannot withstand successive hydration of quick lime. For this reason, Portland cement-based composites and concretes are not suitable for high temperature applications. An indispensable component is aluminous cement, which exhibits excellent resistance to high temperature.

Luminous cement production uses a great deal of energy, because of the higher burning tempera- 


\begin{tabular}{lcccccccc}
\hline & $\mathrm{Al}_{2} \mathrm{O}_{3}$ & $\mathrm{CaO}$ & $\mathrm{SiO}_{2}$ & $\mathrm{Fe}_{2} \mathrm{O}_{3}$ & $\mathrm{MgO}$ & $\mathrm{TiO}_{2}$ & LOI & Blaine $\left[\mathrm{m}^{2} / \mathrm{kg}\right]$ \\
\hline Cement & 70.8 & 27.5 & 0.58 & 0.42 & 0.21 & 0.37 & 0.49 & 381 \\
Metakaolin & 41.9 & 0.13 & 52.9 & 1.08 & 0.18 & 1.8 & 3.81 & 306 \\
Ceramic Powder & 20.26 & 10.92 & 50.73 & 6.36 & 4.75 & - & 6.98 & 336 \\
\hline
\end{tabular}

TABLE 1. Chemical composition of binder components [1, 15] (in \%).

ture (about $1700^{\circ} \mathrm{C}$ ). For this reason, there have been many attempts to find materials with cementitious properties that could replace part of the cement. Much attention in the field of refractories is currently being paid to various clay-based materials, such as metakaolin and ceramic waste powder [1]. The lower energy consumption of these cement supplementation materials could also be more economical. Modern composites are often a complex system with a binder modified by mineral additives and a number of other chemical admixtures. Thanks to advanced technologies, it is possible to achieve desirable properties such as high strength and good durability, for which an extremely low water-cement ratio is required [11.

According to the manufacturing technology for monolithic refractories based on hydraulic bonding, cement composites should reach maturity, after which a drying procedure and the first firing are carried out. A high heating rate may cause mechanical breakage of the refractory. This is most likely to occur if the concrete is held at a low temperature $\left(<21^{\circ} \mathrm{C}\right)[12$.

In particular, the components of refractory composites are usually contaminated with small amounts of impurity oxides, including $\mathrm{TiO}_{2}, \mathrm{Fe}_{2} \mathrm{O}_{3}, \mathrm{CaO}, \mathrm{MgO}$ and alkali oxides, which act as fluxing agents at high temperatures. These fluxing agents reduce the eutectic temperature of alumina-silicate refractories. However, the number of fluxes is kept to a minimum, in order to minimize their effect on the development of the liquid phase at higher temperatures [13, 14].

The aim of the research work presented here is to develop high temperature resistant composites, based on aluminous cement, that offer significant environmental benefits. Two different mineral additives were used as a partial replacement for aluminous cement. Further application of alternative binding systems could reduce the negative impact of the building industry on the environment. The additives investigated here are interesting locally-available alternative raw materials.

\section{MATERIALS AND METHOdS}

Aluminous cement. The refractory composites were based on aluminous cement in order to achieve the required high temperature resistance, which is determined by the content of $\mathrm{Al}_{2} \mathrm{O}_{3}$. Secar71 aluminous cement containing $\geq 71 \%$ of $\mathrm{Al}_{2} \mathrm{O}_{3}$ ) was used in our experimental program. The chemical composition and the specific surface area measured by Blaine apparatus are shown in Table 1. This composition enables the cement to be applied at up to $1700^{\circ} \mathrm{C}$.
Finely ground ceramic powder. To increase the energy efficiency of the composites, we used finelyground ceramic powder that originated from grinding advanced hollow brick blocks produced by Heluz cihlářský průmysl, v.o.s., Czech Republic. Finely-ground ceramic powder is a waste material of major scientific interest in the Czech Republic. Its potential for practical use in the building industry has been confirmed by several research studies [14 19]. However, its use for substituting aluminous cement is a quite novel approach. Its chemical composition is shown in Table 1 .

Metakaolin. Another part of the experiment focused on the impact of adding Mefisto L05 metakaolin from České lupkové závody, a.s., Czech Republic, on the final and residual mechanical properties of refractory composites. Metakaolin is produced by controlled clay calcination. The calcination temperature is dependent on the actual composition of the raw materials, but is generally about $800^{\circ} \mathrm{C}[20]$. The composition of the raw clay, predominantly its kaolinite content, defines the final designation of the product [21].

Ceramic aggregate. Ceramic aggregate in the form of chamotte fireclay was used as a filler. Fireclay aggregates are commercially-produced artificial materials used for producing temperature-resistant elements. The amount of aluminous oxides (a minimum of 40 has an essential influence on the aggregates that are used. The amount of $\mathrm{Fe}_{2} \mathrm{O}_{3}$, which has a negative effect on the temperature resistance, is limited to $4 \%$ [22]. The fireclay is crushed and is distributed in the required grading. A suitable composition of ceramic aggregates ensures that it can be applied at over $1700^{\circ} \mathrm{C}$, which is of great interest in the metallurgical and chemical industries. The refractory quality of high-alumina materials is usually higher than that of fireclay-bearing refractories. Nevertheless, fireclay refractories are still the most widely used type, due to their ease of fabrication, their resistance to chemical attack and their relatively low cost [14].

Basalt fibers. Natural basalt is a material of volcanic origin that is found all over the world. It is primarily resistant to corrosion in an acid environment, and also in an alkaline environment, and is characterized by excellent resistance to high and low temperatures, from $-260{ }^{\circ} \mathrm{C}$ to $+750{ }^{\circ} \mathrm{C}$. Igneous basalt rocks have a sufficient melting temperature, between 
VOL. 56 NO. $1 / 2016$ Residual Properties of Fiber-reinforced Refractory Composites with a Fireclay Filler

\begin{tabular}{|c|c|c|c|c|c|c|c|c|c|}
\hline & \multicolumn{2}{|c|}{ Basalt fibres } & \multirow{2}{*}{$\begin{array}{l}\text { Aluminous } \\
\text { Cement }\end{array}$} & & \multicolumn{3}{|c|}{ Fireclay } & \multirow[t]{2}{*}{ Plasticizer } & \multirow[t]{2}{*}{ Water } \\
\hline & $6.35 \mathrm{~mm}$ & $12.7 \mathrm{~mm}$ & & & $0 / 1 \mathrm{~mm}$ & $1 / 2 \mathrm{~mm}$ & $2 / 4 \mathrm{~mm}$ & & \\
\hline Ref-0 & 0 & 0 & 900 & & 520 & 140 & 320 & 16.2 & 200 \\
\hline Ref-0.5 & 1.45 & 13.05 & 900 & & 520 & 140 & 320 & 16.2 & 200 \\
\hline \multirow[t]{3}{*}{ Ref- 2.0} & 5.8 & 52.2 & 900 & & 520 & 140 & 320 & 16.2 & 200 \\
\hline & \multicolumn{2}{|c|}{ Basalt fibres } & \multirow{2}{*}{$\begin{array}{l}\text { Aluminous } \\
\text { Cement }\end{array}$} & \multirow{2}{*}{$\begin{array}{l}\text { Ceramic } \\
\text { Powder }\end{array}$} & \multicolumn{3}{|c|}{ Fireclay } & \multirow[t]{2}{*}{ Plasticizer } & \multirow[t]{2}{*}{ Water } \\
\hline & $6.35 \mathrm{~mm}$ & $12.7 \mathrm{~mm}$ & & & $0 / 1 \mathrm{~mm}$ & $1 / 2 \mathrm{~mm}$ & $2 / 4 \mathrm{~mm}$ & & \\
\hline CP10-0 & 0 & 0 & 810 & 90 & 520 & 140 & 320 & 16.2 & 200 \\
\hline CP10-0.5 & 1.45 & 13.05 & 810 & 90 & 520 & 140 & 320 & 16.2 & 200 \\
\hline CP10-2.0 & 5.8 & 52.2 & 810 & 90 & 520 & 140 & 320 & 16.2 & 200 \\
\hline CP20-0 & 0 & 0 & 720 & 180 & 520 & 140 & 320 & 16.2 & 200 \\
\hline CP20-0.5 & 1.45 & 13.05 & 720 & 180 & 520 & 140 & 320 & 16.2 & 200 \\
\hline CP20-2.0 & 5.8 & 52.2 & 720 & 180 & 520 & 140 & 320 & 16.2 & 200 \\
\hline CP30-0 & 0 & 0 & 630 & 270 & 520 & 140 & 320 & 16.2 & 200 \\
\hline CP30-0.5 & 1.45 & 13.05 & 630 & 270 & 520 & 140 & 320 & 16.2 & 200 \\
\hline \multirow[t]{3}{*}{ CP30-2.0 } & 5.8 & 52.2 & 630 & 270 & 520 & 140 & 320 & 16.2 & 200 \\
\hline & \multicolumn{2}{|c|}{ Basalt fibres } & \multirow{2}{*}{$\begin{array}{l}\text { Aluminous } \\
\text { Cement }\end{array}$} & \multirow{2}{*}{$\begin{array}{l}\text { Meta- } \\
\text { kaolin }\end{array}$} & \multicolumn{3}{|c|}{ Fireclay } & \multirow[t]{2}{*}{ Plasticizer } & \multirow[t]{2}{*}{ Water } \\
\hline & $6.35 \mathrm{~mm}$ & $12.7 \mathrm{~mm}$ & & & $0 / 1 \mathrm{~mm}$ & $1 / 2 \mathrm{~mm}$ & $2 / 4 \mathrm{~mm}$ & & \\
\hline MK10-0 & 0 & 0 & 810 & 90 & 520 & 140 & 320 & 16.2 & 200 \\
\hline MK10-0.5 & 1.45 & 13.05 & 810 & 90 & 520 & 140 & 320 & 16.2 & 200 \\
\hline MK10-2.0 & 5.8 & 52.2 & 810 & 90 & 520 & 140 & 320 & 16.2 & 200 \\
\hline MK20-0 & 0 & 0 & 720 & 180 & 520 & 140 & 320 & 16.2 & 200 \\
\hline MK20-0.5 & 1.45 & 13.05 & 720 & 180 & 520 & 140 & 320 & 16.2 & 200 \\
\hline MK20-2.0 & 5.8 & 52.2 & 720 & 180 & 520 & 140 & 320 & 16.2 & 200 \\
\hline MK30-0 & 0 & 0 & 630 & 270 & 520 & 140 & 320 & 16.2 & 200 \\
\hline MK30-0.5 & 1.45 & 13.05 & 630 & 270 & 520 & 140 & 320 & 16.2 & 200 \\
\hline MK30-2.0 & 5.8 & 52.2 & 630 & 270 & 520 & 140 & 320 & 16.2 & 200 \\
\hline
\end{tabular}

TABLE 2. Composition of the mixtures (all data in $\mathrm{kg} / \mathrm{m}^{3}$ ).

$1500^{\circ} \mathrm{C}$ and $1700{ }^{\circ} \mathrm{C}$, which enables them to be used in the form of fibers in a wide range of industrial applications 23, 24. Basalt fibers are predominantly produced in the form of a continuous fiber, which is cut to the required length. There has been intensive development of basalt fibers in the form of textiles, bars, rovings, etc., because, unlike toxic asbestos fibers, they pose no health risks [9]. For our study, we used fibers produced by the Basaltex, a.s., Czech Republic. The density of the basalt fibres corresponds with the density of the raw material $\left(2900 \mathrm{~kg} / \mathrm{m}^{3}\right)$. The tensile strength of basalt fibres is more than $2000 \mathrm{MPa}$.

The experimental program investigated the composition of refractory fiber-reinforced composites and their response to gradual thermal loading. The evaluation was based on determining the basic physical and mechanical properties. The binder system was modified by adding ceramic powder and metakaolin. The mineral additives were gradually dosed up to $30 \%$ of cement substitution. The mixtures were reinforced by two different dosages of basalt fibers $(0.5 \%$ and $2.0 \%$ by volume). It is necessary to apply an efficient plasticizer in order to preserve good workability and a low water-cement ratio. On the basis of previous research, we decided to use polycarboxylate plasticizer in a dosage of $2.5 \%$ of the binder mass. No negative impact of this organic compound on the residual properties was confirmed 25].

The composite was composed with three fractions of finely-crushed fireclay aggregates: $0-1 \mathrm{~mm}, 1-2 \mathrm{~mm}$ and $2-4 \mathrm{~mm}$. These fractionswere used, because their absence could reduce the final mechanical properties.

Previous research had confirmed a positive impact of dosing fibres of different lengths [26]. To achieve better fracture properties and to limit crack initiation, it is more effective to use longer fibres. For this reason, fibres $6.35 \mathrm{~mm}$ and $12.7 \mathrm{~mm}$ in length and $13 \mu \mathrm{m}$ in diameter were added in doses of $0.5 \%$ and $2.0 \%$ by volume. The greater amount of fine components in the mixture was designed to ensure good spatial distribution of the basalt fibers. This reinforcement was applied for each modification of the binder with finelyground ceramic powder (CP) and metakaolin (MK). Details of the composition of all studied composites are shown in Table 2. Sets of prismatic specimens with dimensions of $40 \times 40 \times 160 \mathrm{~mm}^{3}$ were produced 


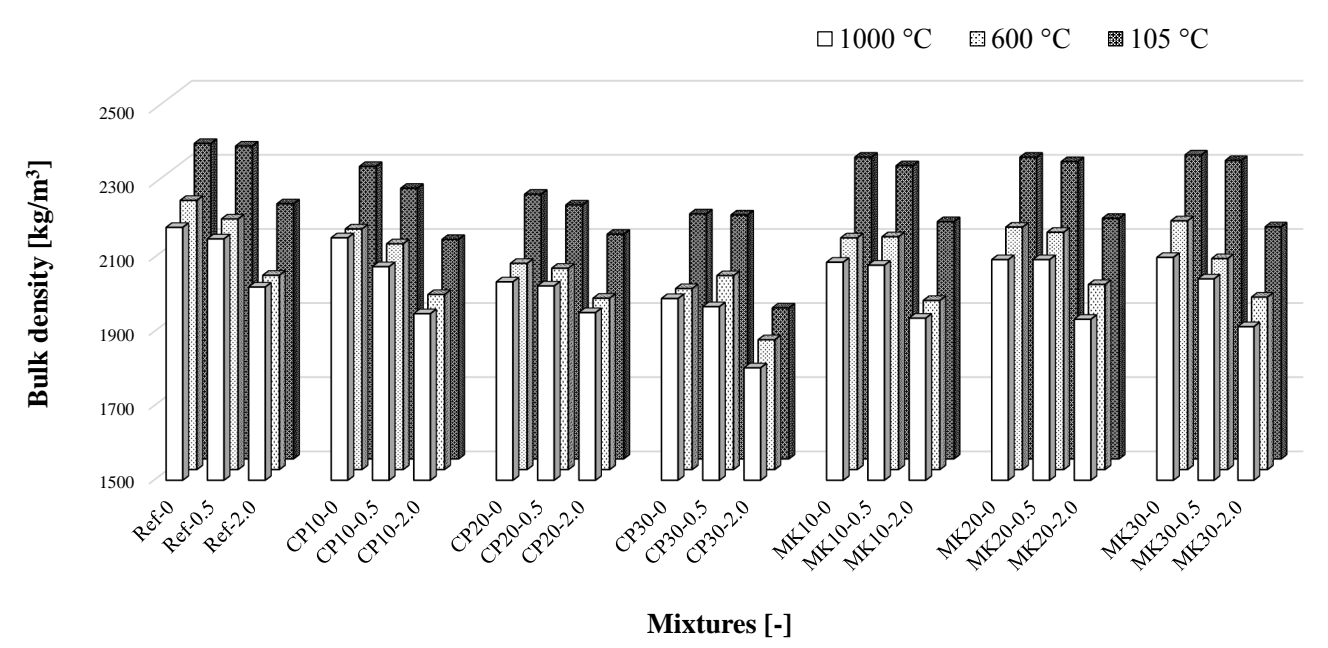

Figure 1. Bulk density of the tested composites.

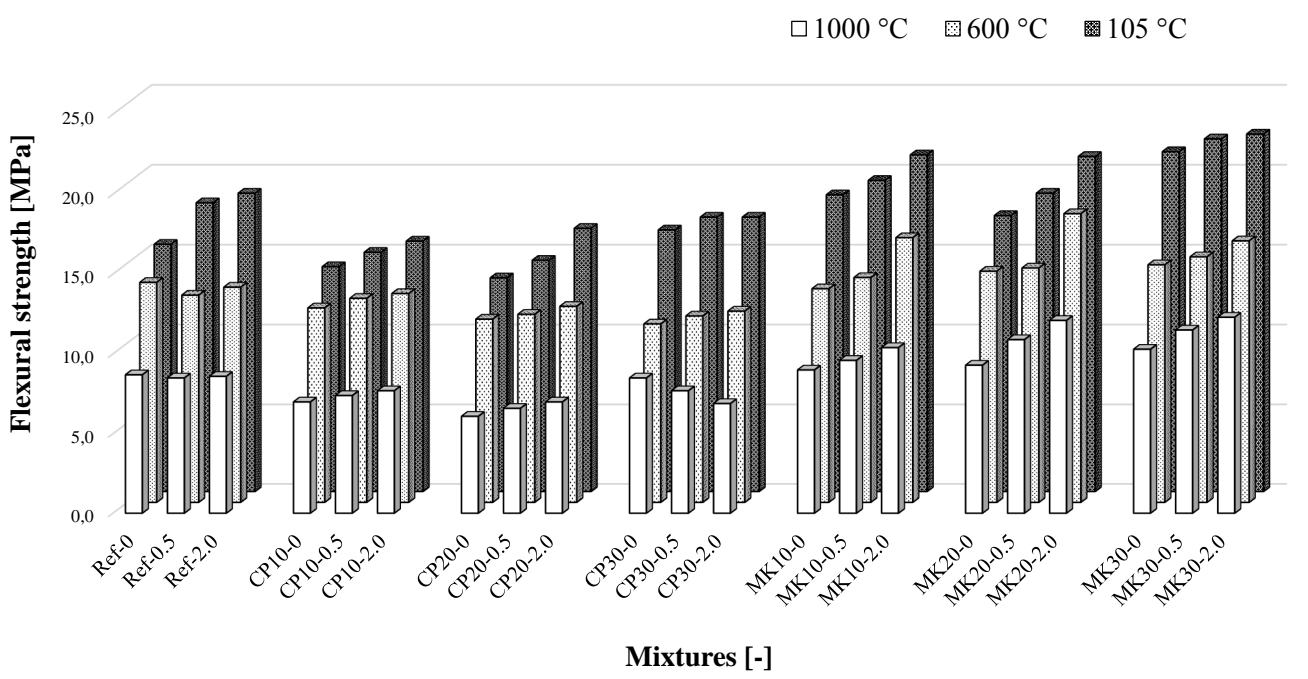

Figure 2. Flexural strength of the tested composites.

for the tests that followed.

We can observe a gradual decline in bulk density due to the effect of high temperature, when the moisture and the physically-bound water have evaporated. The increase in the temperature load leads to a further decrease in bulk density, which is caused by partial chemical decomposition of the hydration products and the siliceous components contained in the additives. For this reason, the highest bulk density values can be observed for the reference specimens without cement replacement, see Fig. 1. The bulk density values are also affected by the increasing application of basalt fibers. Doses of $2.0 \%$ of fibers by volume had an air-entraining effect.

Flexural strength is predominantly affected by the fiber dosage, but the parameters that are reached indicate that increasing the fiber dose extensively seems not to lead to very high parameters. Ceramic powder provided no fundamental improvement in flexural strength, but the residual values, which are crucial for refractories, are slightly lower than the reference. In addition, metakaolin had an altogether positive effect on the flexural strength values in all cement substitutes studied here. Metakaolin replacement has a significant positive effect on the residual values. Detailed results are shown in Fig. 2, which also shows the potential of the cement supplementation materials for refractory composite production.

Substitution of cement offers major environmental benefits and energy savings. The basalt fibers probably have good cohesion with the binder system, because the reduction in bulk density due to high doses of fibers did not have a negative effect on the final flexural strength values.

The compressive strength results are very interesting in relation to the additives studied here. The compressive strength values correspond well with the bulk density result, see Fig. 3. The residual properties of the high temperature resistant composites with the addition of metakaolin reached a similar level or a higher level for all mixtures. This is important, because it limits the negative impact of an additive with a relatively high amount of quartz, which passes through several phase changes during thermal loading. Our data corresponds with that presented in Keppert [10. 


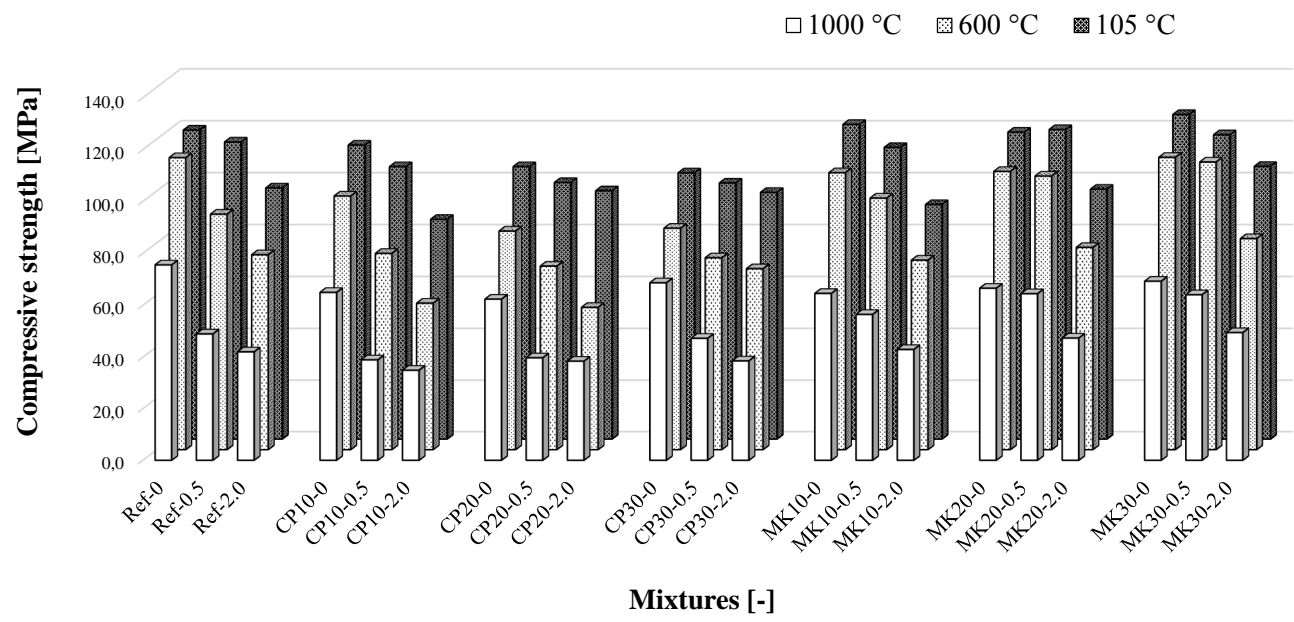

Figure 3. Compressive strength of the tested composites.

\section{Conclusion}

The experimental program that has been carried out dealt with the development of a new refractory fiberreinforced composite using alternative binding materials. The program focused on the application of a finely-ground ceramic powder and metakaolin as a replacement for aluminous cement. Our aim was to develop a high temperature resistant fiber-reinforced composite with reduced environmental impacts. The basic physical and mechanical properties before and after temperature loading were measured in order to evaluate the behaviour of the system.

On the basis of the experiments that we performed, we can conclude that, in terms of flexural and compressive strength and residual strength after temperature loading, the most suitable properties are achieved when $270 \mathrm{~kg} / \mathrm{m}^{3}$ of aluminous cement $(30 \%$ of the aluminous cement weight) are replaced by metakaolin. The residual mechanical properties of all mixtures with added ceramic powder exhibited slightly lower values than those of the reference mixtures with full doses of aluminous cement. The reduction was by about $15 \%$.

Substitution of aluminous cement contributed to the stability, and also to the mean ratio of the original and residual properties, of the fiber-refractory composites that were developed. After $600{ }^{\circ} \mathrm{C}$, the flexural strength decreases to $71.0 \%$ of the original value, while the compressive strength decreases to $87.8 \%$ of the original value. A similar trend, $51.9 \%$ of the original values for flexural strength and $61.0 \%$ for compressive strength, can be observed after $1000^{\circ}$ Cloading. This is probably caused not only the suitable composition of the additives, but also by the improved grading curve of the fine components. This corresponds with the research findings presented by Fujiwara et al [30]. A secondary consequence this effect is that there is improved efficiency of the basalt fibers, due to better cohesion.

Our experimental program has confirmed the great potential of ceramic powder, and especially metakaolin, as a supplementation material for aluminous cement in high alumina cement based composites. Further application of materials based on burnt clay and brick dust can help to reduce energy consumption and total costs.

\section{ACKNOWLEDGEMENTS}

The authors gratefully acknowledge the support provided by the Czech Science Foundation under project P104/12/0791: Fibre-Reinforced Cement Composites for High Temperature Applications.

\section{REFERENCES}

[1] Koňáková, D., et al.: Influence of Metashale as Cement Replacement on the Hygric Transport Properties of Concrete, Advanced Materials Research 1054 (2015) 188-193. DOI:10.4028/www.scientific.net/AMR.1054.188

[2] Sadik, Ch., Amrani, I.-E.E., Albizane, A.: Recent advances in silica-alumina refractory: A review, Journal of Asian Ceramic Societies 2 (2006) 83-96. DOI:10.1016/j.jascer.2014.03.001

[3] Katsavou, I.D., Krokida, M.K., Ziomas, I.C.: Determination of mechanical properties and thermal treatment behaviour of alumina-based refractories, Ceramics International 38 (2012) 5747-5756. DOI:10.1016/j.ceramint.2012.04.021

[4] Mirza, F.A., Soroushian, P.: Effects of alkali-resistant glass fiber reinforcement on crack and temperature resistance of lightweight concrete, Cement and Concrete Composites 24/2 (2002) 223-227. DOI:10.1016/S0958-9465(01)00038-5

[5] Gao, J., Sun, W., Morino, K.: Mechanical properties of steel fiber-reinforced, high-strength, lightweight concrete, Cement and Concrete Composites 19/4 (1997) 307-313. DOI:10.1016/S0958-9465(97)00023-1

[6] Kavali, O., Haque, M. N., Zhu, B.: Some characteristics of high strength fiber reinforced lightweight aggregate concrete, Cement and Concrete Composites 25/2 (2003) 207-213. DOI:10.1016/S0958-9465(02)00016-1

[7] Libre, N.A., et al..: Mechanical properties of hybrid fiber reinforced lightweight aggregate concrete made with natural pumice, Construction and Building 
Materials 25/5 (2011) 2458-2464. DOI:10.1016/j.conbuildmat.2010.11.058

[8] Zanotti, C., Banthia, N, Plizzari, G.: A study of some factors affecting bond in cementitious fiber reinforced repairs, Cement and Concrete Research 63 (2014) 117-126. DOI:10.1016/j.cemconres.2014.05.008

[9] Mateo, M., Perez-Carraminana, C., Chinchon, S.: Varieties of Asbestos in Buildings and Risks associated with the work of deconstruction, Informes de la construcción 65/531 (2013) 311-324. DOI:10.3989/ic.11.118

[10] Keppert, M. et al.: Microstructural changes and residual properties of fiber reinforced cement composites exposed to elevated temperatures. Cement Wapno Beton 17/2 (2012) 77-89.

[11] Jogl, M. et al.: Proposal of Fire Resistant Composites with Application of Lightweight Aggregate Liaver, Advanced Materials Research 1054 (2014) 43-47. DOI:10.4028/www.scientific.net/AMR.1054.43

[12] Cardoso, F.A. et al.: Effect of curing time on the properties of CAC bonded refractory castables, Journal of the European Ceramic Society 24/7 (2004) 2073-2078. DOI:10.1016/S0955-2219(03)00371-6

[13] Boris, R. et al.: Effect of holding temperature on properties of different types of heat-resistant concrete, Refractories and Industrial Ceramics 54/5 (2014) 397-400. DOI:10.1007/s11148-014-9619-x

[14] Andrews, A., Adam, J., Gawu, S.K.Y.: Development of fireclay aluminosilicate refractory from lithomargic clay deposits, Ceramics International 39/1 (2013) 779-783. DOI:10.1016/j.ceramint.2012.06.091

[15] Scheinherrová L. et al.: Thermal properties of high-performance concrete containing fine-ground ceramics as a partial cement replacement, Materials Science 21/3 (2015). DOI:10.5755/j01.ms.21.3.7160

[16] Kulovaná, T. et al.: Air-entrained concrete technology as an effective tool for increasing the limits of brick powder percentage in blended Portland cement binders, Cement Wapno Beton 20/1 (2015) 11-+.

[17] Bignozzi, M.C., Saccani, A.: Ceramic waste as aggregate and supplementary cementing material: A combined action to contrast alkali silica reaction (ASR), Cement and Concrete Composites 34/10 (2012) 1141-1148. DOI:10.1016/j.cemconcomp.2012.07.001

[18] Katzer, J.: Strength performance comparison of mortars made with waste fine aggregate and ceramic fume, Construction and Buildings Materials 47 (2013) 1-6. DOI:10.1016/j.conbuildmat.2013.04.039
[19] Reiterman, P. et al.: Fracture Properties of Cement Pastes Modified by Fine Ground Ceramic Powder, Advanced Materials Research 1054 (2014) 182-187. DOI:10.4028/www.scientific.net/AMR.1054.182

[20] Vimmrová, A. et al.: Calcined gypsum-lime-metakaolin binders: Design of optimal composition, Cement and Concrete Composites 52 (2014) 91-96. DOI:10.1016/j.cemconcomp.2014.05.011

[21] Siddigue, R., Klaus, J.: Influence of metakaolin on the properties of mortar and concrete: A review, Applied Clay Science 43/3-4 (2009) 392-400. DOI:10.1016/j.clay.2008.11.007

[22] Eze, E.O., Onabanjo, S.A.: Heating effects on physical and strength characteristics of fireclay from the Nigerian Coal Measures Formation, Applied Clay Science 9/5 (1995) 397-406. DOI:10.1016/0169-1317(94)00024-K

[23] Jiang, Ch. et al.: Experimental study on the mechanical properties and microstructure of chopped basalt fibre reinforced concrete, Materials and Design 58 (2014) 187-193. DOI:10.1016/j.matdes.2014.01.056

[24] Slivka, V., Vavro, M.: The significance of textural and structural properties of north-Moravian basaltoids for the manufacture of mineral fibres, Ceramics 40/4 (1996) 149-159. Scopus: 2-s2.0-0030383190

[25] Jogl, M. et al.: Influence of high-temperature on polycarboxylate superplasticizer in aluminous cement based fibre composites, Advanced Materials Research 982 (2014) 125-129. DOI:10.4028/www.scientific.net/AMR.982.125

[26] Holčapek, O., Reiterman, P., Konvalinka, P.: Fracture characteristics of refractory composites containing metakaolin and ceramic fibers, Advances in Mechanical Engineering 7/3 (2015) 1-13. DOI:10.1177/1687814015573619

[27] Pacewska, B. et al.: Studies on the influence of spent FCC catalyst on hydration of calcium aluminate cements at ambient temperature, Journal of Thermal Analysis and Calorimetry 105/1 (2011) 129-140. DOI:10.1007/s10973-011-1303-5

[28] Reiterman, P., Holčapek, O., Jogl, M., Konvalinka, P.: Physical and Mechanical Properties of Composites Made with Aluminous Cement and Basalt Fibers Developed for High Temperature Application, Advances in Materials Science and Engineering, 2015. DOI:10.1155/2015/703029

[29] Czech Standard CSN EN 196-1 Methods of testing cement - Part 1: Determination of strength, 2005.

[30] Fujiwara H. et al.: Study on reducing unit powder content of high-fluidity concrete by controlling powder particle size distribution, Concrete Library of JSCE 532 (1996) 117-128. 